Article

\title{
Rethinking the Thinking on Democracy in Education: What Are Educators Thinking (and Doing) About Democracy?
}

\section{David Zyngier}

Education Faculty, Peninsula Campus Monash University, Melbourne 3199, Australia; E-Mail: david.zyngier@monash.edu; Tel.: +61-3-9904-4320; Fax: +61-3-9904-4027

Received: 9 November 2011; in revised form: 7 December 2011 / Accepted: 19 December 2011 / Published: 21 December 2011

\begin{abstract}
This paper examines perspectives and perceptions of democracy of pre- and in-service teachers as well as teacher-education academics in Australia in order to develop a robust and critical democratic education. Using data from an on-line survey the paper presents the quantitative analyses, and the qualitative responses of contrasting understandings of democracy, citizenship and the role of education in the promotion and development of an active and thick democracy the paper critiques the neo-liberal (thin) democratic discourse of contemporary Australian academic research that suggests that the Civics and Citizenship Education project only requires some augmentation highlighting issues like sustainability and globalization while ignoring social justice issues. It begins by outlining the concepts of thick and thin democracy, and revisits the state of civics and citizenship education (CCE) in Australia. It is argued that while the pre-service teachers in this study may have a more critical and thicker understanding of democracy that is mirrored in the views of their teacher-education professors, the practicing teachers, on the other hand, have largely adopted the mainstream neo-liberal discourse, presenting a tendency to view democracy in a very narrow or thin way that may impact on their classroom practice. The paper concludes with recommendations related to what a thick democracy might actually look like in school education.
\end{abstract}

Keywords: civics and citizenship education; neo-liberalism; democracy; critical pedagogy 


\section{Introduction}

While there have been important studies of how school students understand democracy and democratic participation ${ }^{1}$ there has been no such study of teachers and teacher educators. This paper analyzes how Australian educators perceive, experience and understand democracy, especially related to education and suggests how educators might contribute to the development of a more robust, thicker educational experience for their students?

Determining the linkage between education and democracy is important as it may have implications for how students themselves relate to democracy [1] both in the classroom and in the education faculty. This paper is informed by the need to critically understand the perspectives and experiences of educators in relation to democracy in education $[2,3]$.

This paper reports on research arising from the international Global Doing Democracy Research Project (GDDRP) ${ }^{2}$, which currently has some 70 scholars in over 20 countries examining perspectives and perceptions of democracy among pre- and in-service teachers, teacher education academics, and educators, in general. It uses a collaboratively developed and locally contextualised on-line survey tool to collect both quantitative and qualitative data from diverse groups of educators ${ }^{3}$. Each researcher is responsible for the analysis of the data within the shared critical pedagogical framework that was originally developed by Carr [4]. The aim of the research, ultimately, is to compare and contrast these findings and implications across diverse political contexts, including the old democracies (countries such as the USA, Australia, Canada, England), emerging democracies (those countries coming out of autocratic, military or other dictatorships and or colonial rule), and what we have termed the new democracies (places and countries that are doing democracy differently as a result of public initiatives found in Latin America and elsewhere). Our research highlights:

(1) The apparent predisposition among education-students (future teachers) and educators to understand democracy and politics in a thin way;

(2) The potential for university education teachers and classroom teachers to do transformative or thick democracy in education;

(3) The importance of understanding power and difference in relation to democracy; and

(4) The cultivation of a critically and meaningfully engaged educational experience that links social justice to education and democracy.

\section{The Need to Understand the Perspectives, Experiences and Perceptions of Teachers in Relation to Democracy in Education}

Studying the perspectives, experiences and perceptions of educators, and how they understood cultivate and anchor democracy within the educational experience, is considered to be an important

\footnotetext{
${ }^{1}$ IEA-CIVED Civic education study 1999 and 2005.

2 The Global Doing Democracy Research Project was established in 2008 by David Zyngier and Paul Carr who are co-directors. While there are many on-line networks created among academics for the exchange and sharing of ideas, the development of such an on-line activist research group focused on democracy and democratic education is uncommon.

${ }^{3}$ At this time the on-line survey has been translated in to Portuguese, Spanish, Bhasa Malay, Greek, Turkish, French, Bosnian and Moldavian. It is currently being translated into Farsi, Kazakhstani, Azerbaijani, Hindi, Urdu, Tamil and has been adapted and applied in over 30 international contexts. The comparative analysis of these is an on-going and major task for the Global Doing Democracy Project.
} 
piece of the equation in the development of a more participatory, empowered and engaged citizenry, thereby safeguarding our democratic society.

\subsection{Thin and Thick Democracy}

Democracy means many things to many people. The us versus them paradigm of democrats and non-democrats has been problematic, and even disenfranchising for many citizens, as evidenced by the limited and decreasing participation in elections, especially among youth). The research project which this paper reports on, seeks a more robust, critical, thicker interpretation of what democracy is, what it should be, and, significantly, how it can be beneficial to all peoples [4]. The research critiques the belief that elections the key component to building a democracy. The research of the author and his associates and others over the past several years has raised the pivotal concern of the role education in forming, buttressing, cultivating and sustaining a meaningful, critical democratic experience for all sectors of society $[1,5,6])$. The shift and acceptance toward market-based neo-liberalism in education has had a wide range of effects and consequences on society which are well documented and accepted [7].

Democracy must be constantly cultivated, conceptualized and re-worked, with less dependence on the formal political process and cycle of elections, and more on critical engagement in developing the conditions for emancipation, enhanced power relations, and epistemological discovery that may lead to some of the virtues that are commonly extolled when discussing democracy (freedom, liberty, rights, common virtues, etc.). Critical pedagogy offers a framework to understand political literacy and social transformation, in which static representations of power, identity, and contextual realities are rejected [8-10]. CP is not about providing a checklist against which one can determine the level of democracy within a given society [3], rather, it is concerned with oppression and marginalization at all levels, and seeks to interrogate, problematize and critique power and inequitable power relations.

The traditional approach in civics/citizenship education in schools focuses on an understanding of formal political structures, and is often, problematically, isolated to a single unit of study in both primary and secondary education. Preliminary research undertaken by team-members in this project underscores how educators in Canada, USA, Peru, Argentina, Brazil, Malaysia and Australia have, generally, only a superficial conceptualization of democracy [11,12] see also [13]. This paper analyzes part of the GDDRP data collected in Australia. It seeks to understand, complexify and contextualize how those involved in school education comprehend, experience, perceive, and implement democracy in education. Attempting to determine the linkage between education and democracy at the educator level is important as we believe that it may have far-reaching implications for the delivery of teaching and learning that subsequently influences how students relate to, and do, democracy [1,5] within the classroom, within the school and, more broadly, at the societal level. The broad objective of the Global Doing Democracy Research Project is to collect and analyse data from a significant number of participants from diverse contexts in order to determine with greater authority how democracy is perceived, experienced and undertaken in and through education. The result would then enable the elaboration of specific tools, measures and practices at the local, national and international levels, taking into consideration where diverse constituencies start as well as their contemporary realities. 
The discourses over democracy have been variously characterized in terms of representative versus participatory democracy ${ }^{4}$, with the former highlighting thin electoral processes, and the latter focusing on thick critical engagement and social justice. The notion of thick and thin democracy attributed to Gandin and Apple [14], building on the seminal work of Barber [15,16]. Barber raised pivotal questions on the saliency of liberal democracy, including the tension between individualism and the rights of all citizens framed by concepts of shallow and deep democracy. This tension has been problematic and even disenfranchising for many citizens.

What Furman and Shields [17] call 'deep' democracy' attaches "significant value to such goods as participation, civic friendship, inclusiveness and solidarity" (p. 128). Deep or thick democracy, according Furman and Shields, espouses a number of principles that champion individual rights and responsibility within diverse cultural communities in the interests of the common good. These include:

- respect for the worth and dignity of individuals and their cultural traditions;

- reverence for, and proactive facilitation of, free inquiry and critique;

- recognition of interdependence in working for the common good;

- responsibility of individuals to participate in free and open inquiry; and

- re-affirmation of the necessity for collective choices and actions in the interest of the common $\operatorname{good}[17]$.

In practice, thin democracy is exemplified in activities such as students contributing to a food drive, whereas thick democracy would explore why people are hungry [1]. Through the notion of thin versus thick democracy, we conceptualize the visible tension between the superficial features often associated with teaching about democracy and the fundamental scaffolding which permits people to appropriate the deeper meaning of the term teaching for democracy. Bolstering efforts to teach through the academic disciplines-whether pursued through high-stakes exams or well-crafted curriculum frameworks - is insufficient to further the goals of teaching for democracy [18].

In Australian school education this tension has played out in the Civics and Citizenship Education (CCE) program. The rhetoric of active participation found in these programs usually is "not achieved in the activities that are provided for school students" [18]. Dejaeghere and Tudball [19] conclude that most recent assessments of the CCE program suggest "further work is required to promote depth and breadth". The lack of agreement around the philosophical and practical applications of education for democracy [3] led to the exclusion of concerns about social justice from the material distributed nationally to every school which was orientated towards a thin understanding of democracy. Giroux [20] boldly states that

Democracy cannot work if citizens are not autonomous, self judging, and independent - qualities that are indispensable for students if they are going to make vital judgments and choices about participating in and shaping decisions that affect everyday life, institutional reform, and governmental policy. (p.73)

Schwille and Amadeo [21] in their analysis of the Civic Education Study (CIVED 1999 and 2005) argue that "as long as parts of the political system aspire to foster active, informed and supportive

\footnotetext{
${ }^{4}$ Others have referred to democratic binaries such as weak and strong Swift (2002), passive and active (Criddle, Vidovich,
} \& O'Neill, 2004), minimalist and maximalist (McLaughlin, 1992). 
citizens, schools will be considered a possible means to this end" (p. 105). Schools which model democratic practices in classrooms, by creating an open climate for discussing issues, are most effective in promoting civic knowledge and engagement in thick ways; however this is rarely found in schools [22].

\subsection{New Civics as Thin Democracy}

The CCE project in Australia, like others elsewhere, places a "growing emphasis on the promotion of civic awareness and individuals' rights and responsibilities embedded in discourses of citizenship" [23], highlighting the conflicting discourses in approaches to citizenship education [24], which "permeate both policy production and policy practices across all levels" (p. 32). On the one hand, there is an emphasis on passive consumption of knowledge about citizenship with a strong historical focus - thin democracy - and, on the other, critical and active participation ${ }^{5}$ in change, which is labelled as an 'active citizenship'-thick democracy.

The CCE Project has been extensively critiqued by many researchers [25-28] for its restricted or thin scope. The CCE Project in Australia has been the result of the struggle over how democracy is perceived - and it has been the thin conceptions of citizenship [29] privileging the "aggregation of individual votes ... [that] endorses hierarchy, elite agency and mass passivity" [30] - that has been dominant. Davies and Issitt argue that CCE "seems in the eyes of policy-makers to be the instrument by which societies can find a way still to cohere in the face of new challenges" and compensate for "civic deficit" [18] concluding that this form of thin democracy has promoted a pragmatic conservatism.

\section{Conceptual Framework and Methodology}

Previous research in the USA and Canada $[2,3,31]$ found that educators had a thin understanding of democracy concerned more with elections than participation. This research has Human Research Ethics Committee and Department of Education and Early Childhood Development approval.

Critical Pedagogy (CP) underpins the analytical approach to understanding how democracy is perceived. CP considers how education can provide individuals with the tools to better themselves and strengthen democracy in order to create a more egalitarian and just society. It seeks to empower the powerless and transform those conditions which perpetuate human injustice and inequity. Unlike traditional perspectives of education claiming to be neutral and apolitical, critical pedagogy views all education theory as intimately linked to ideologies shaped by power, politics, history and culture. Using this framework of analysis signals how questions of audience, voice, power, and evaluation actively work to construct particular relations between teachers and students and classrooms and communities illuminating the relationship among knowledge, authority, and power.

A validated instrument [3] was modified for the Australian context, and then administered anonymously on-line to teachers (Ts), pre-service teachers (PSTs) and teacher educators (TEs), to identify their beliefs about democracy. It contained approximately thirty open and closed questions in

\footnotetext{
${ }^{5}$ There are examples of these radical intentions for example in the unit on the Freedom Fighters which seemingly defies any neo-liberal interpretation. It is about indigenous activists in Australia in the 1960s. There are certainly problems, but there are also some good examples of both content and pedagogy and while these are acknowledged it remains that overall the materials support a broadly conservative approach to history and politics.
} 
three sections: (1) an introductory section requesting demographic information; (2) questions on democracy and education; (3) questions on citizenship, social justice and education. We did not define such terms as democracy, citizenship, and social justice to participants but, rather, asked them to do so. In addition to providing a quantitative score based on a Likert scale of 1 to 5 , the survey instrument invited respondents to expand on their answers.

While the research sample may be considered small, the number of respondents in each category represents over $50 \%$ of potential respondents, and includes PSTs $(\mathrm{N}=55)$, Ts $(\mathrm{N}=65)$ and TEs $(\mathrm{N}=40)$ in Australia. The education students and teacher academics were from the same faculty of one of the largest and most research intensive universities in Australia. The in-service teachers were invited to participate from a number of primary schools in the eastern growth corridor of Melbourne. Primary (elementary) teachers are generalists, and are required to teach their classes the broad curriculum except for (on occasion) specialist teachers in the arts, ICT and physical education. The student population of these schools is very diverse with many refugee, migrant and working-class families.

This paper reports only on the questions relating to understanding democracy ${ }^{6}$ and focuses primarily on the narrative comments, alluding occasionally to the quantitative scores as a means of simply providing an overview of the sample studied ${ }^{7}$.

\section{The Research Participants}

The PSTs are part of a primary initial teacher education (ITE) course, predominantly female (80\%) and young, aged between 20 and 25 (70\%). The majority (78\%) attended public secondary (high) schools, over $30 \%$ of their parents were born outside Australia, and over $30 \%$ of their fathers and $40 \%$ of their mothers completed 12 years of schooling or less.

The Ts also were predominantly female, reflecting the current situation in schools today in Australia, and 33\% were very experienced teachers aged between 45 and 50, while 25\% were newer teachers aged between 26-30 years. Only 10\% were born outside Australia, predominantly from English-speaking countries. Their own secondary education split evenly between public and private (Catholic and Independent) schools ${ }^{8}$. Reflecting postwar migration patterns, almost $50 \%$ of their parents were born overseas predominantly, in Europe arriving in Australia with less than 12 years of education.

The TEs reflected women's dominance in the field of with $71 \%$ of respondents being female. The education faculty of this major $\mathrm{GO}^{9}$ university has been recently ranked as well above world standards for research, and more than $50 \%$ of its academic staff are early career researchers. This is reflected in $30 \%$ being under 30 , and $10 \%$ between 30 and $40,45 \%$ between 40 and 50 , and $16 \%$ over 55 years old. As to be expected, 55\% of academic staff's highest degree was a doctorate, the rest holding a masters' degree. $85 \%$ were born in Australia, while 10\% are from England, and the others

\footnotetext{
${ }^{6}$ A detailed analysis of the findings from all the themes is forthcoming in Zyngier (2013) Doing Democratic Education or Just Schooling: the state of democratic education in Australia Information Age Publishers Inc Charlotte NC.

${ }^{7}$ All percentages have been rounded for convenience).

${ }^{8}$ Note that education in Australia has the highest percentage of enrolments in private schools in the OECD with almost $50 \%$ of all secondary students in non public schools. Private schools have been part-funded by the state since the 1970s.

${ }^{9}$ GO8: Group of Eight research intensive universities in Australia. There are 33 universities and 27 education faculties preparing pre-service teachers. All Australian universities bar two are public institutions where students attending need not pay upfront fees but instead may opt for a free loan scheme repaid out of pre-tax earnings after graduation.
} 
from various Asian countries. 49\% attended state secondary schools, 23\% Catholic schools, and 28\% independent or private secondary schools. Significantly over $50 \%$ of their fathers and $48 \%$ of their mothers completed 12 or fewer years of high school education. As has often been the case, school education has been the path of social mobility for aspirational lower-middle and working-class parents. This is reflected in the fact that $37 \%$ of their fathers and $40 \%$ of their mothers migrated to Australia.

\section{Findings}

This section reports on and analyzes some of the key findings in relation to the similarities and differences between the three different groups of respondents in relation to their particular understandings of democracy and how they might include democratic practices in their classroom, and seeks to understand these in relation to the framework of thin and thick democracy.

\subsection{Understanding Democracy}

There was unanimity among all three groups of respondents about the understanding that democracy was about personal freedom of opinion and free and fair elections where governments are chosen by the majority of people. Overall, the vast majority ( $85 \%)$ has a thin conception of democracy with voting and elections as central to democracy, and a narrow or non-existent engagement with alternatives to mainstream political parties. Diversity, when mentioned, was understood in very narrow terms in generally essentialized ways with "limited linkages to ... inequitable power relations" [4].

Yet there were also differences. Many $(65 \%)$ of the PSTs highlighted the "freedom and right to choose" as the essence of democracy. A limited number (25\%) of responses indicated an understanding that democracy was also about recognition of difference and social justice highlighting concepts such as "recognition of universal human rights and laws against discrimination". Many (65\%) of PSTs also highlighted the concept of "power" that needed to be controlled by the people "to the people", where individual rights are of equal value as those of majority or national interests and where:

"no one group of people is given precedence over other groups of people. No one set of beliefs is given greater value over others and active discrimination against any one group, religion, color or creed is prevented by law and by that society's 'norms' and values".

One PST commented that democracy involved "the strongest and noblest people taking the lead for the greater good" which raised caused concerns that while this person would be teaching young children, such an understanding could also be a pre-condition for dictatorship.

The teachers overwhelmingly (85\%) highlighted the concept of "freedom to choose" a government based on rule of law. Working in a highly regulated public service it was notable that number highlighted the requirement to be able to speak freely without fear of retribution or punishment where "everyone has a say ... when people listen and value your opinion". A small minority (10\%) raised issues of social justice "where members of society are treated as equal or social equality" understanding that there is an unequal distribution of power and highlighting an "equal participatory role" where "all citizens have equal input".

Unsurprisingly, the teacher educators wrote more extensively and elaborately about their understanding of democracy, highlighting "equitable social, cultural, economic outcomes". A number 
(35\%) mentioned the need for "active participation" or "involvement" at all levels of society, including public action where "dissent" is a vital part of "critical and public engagement" with "multiple sets of perspectives and values". One cynically wrote that democracy was "carefully constructed, consisting of mono lingual, mono cultural rule governed with illusion to be for the people, but there for the power and money".

Australians are sometimes thought of as a very relaxed and apolitical people, apart from membership of a trade union or professional organization, which have suffered heavy declines in recent years under the continued assault of neo-liberal political and media attacks. Australians do not join political parties as a matter of course, and this is reflected in the perceptions of the respondents about their parents. The PSTs, Ts and TEs believed, respectively, that $88 \%, 71 \%$ and $59 \%$ of their parents were not politically active. This could also reflect a generational viewpoint, with PSTs overwhelmingly being born in the late 1980s at a time of Australia political stability, while the teachers themselves being much older and having lived through the more turbulent 1970s may have considered their parents, who were predominantly post World War Two 'baby boomers', uncommitted and apathetic. There was no apparent significant correlation between education level and employment type of parents and their involvement in politics.

\subsection{Do you Feel Australia is a Democratic Country?}

Graffiti, in all its ugliness, is a mark of democracy and a law banning it is a sign of an undemocratic soul. (TE)

While there was a range of views on how democratic Australia is among the three groups, some issues need to be highlighted. Similar proportions of PSTs (30\%) and TEs $(28 \%)$ indicated that they had some concerns about the degree of democracy that they experienced in this country, while among serving teachers there was no one who believed that Australia was not democratic; in fact all believed that Australia was very democratic.

The PSTs who felt this way raised issues in relation to minority groups, especially the treatment of Australian Indigenous (First Nations) People, and those groups of people with limited access to the instruments of power (social, cultural and economic capital). These respondents, while in a minority, were able to differentiate between thin conceptions of democracy that emphasize elections and superficial equality of rights and a thicker democracy beyond voting to establish a clear connection with social justice. Typical comments from these respondents stated that "There are many disenfranchised people ... some groups in society are disadvantaged in this system ... many voices are silenced, including the many indigenous languages ... we still need a lot of work when it comes to our own indigenous people". A very small number of PSTs also referred to power imbalances between social and economic groups because "the minority hold(s) the power and the voice in major decisions". Some comments, in particular, reflected a thicker democratic analysis of class and social hegemony [32-34] stating that "there are very narrow ideas about education, ways of life, and languages dominating school systems ... people don't have full freedom because of their economic or social status".

TEs who were negative about Australia's thinness of democracy commented that "full participation (is) often dependent on who you are and where you live". They referred to the rhetoric of democracy 
being "strictly reduced to majority vote via a political system which serves to turn the majority off from politics. Our representative system does not include enough public forums or encouragement to be involved in political matters of a public nature".

A significant minority of TEs $(20 \%)$ were prepared to call Australia undemocratic, highlighting that while "we flaunt that we have freedom of speech, equal rights and are fair to all, you will be thrown in jail before you actually get the chance to speak what you believe is wrong or should be changed". Further, many mentioned the "class based distribution of power" leading to reduced democracy.

Some referred to current issues as involving the lack of democratic rights of Asylum Seekers and so-called illegal arrivals who "(we) lock away in detention centers and we do not accept our so called 'friends and allies' as climate refugees, who are suffering for the greed and consumption of the mining companies which our government protects above all". Alluding to the disproportionate distribution of power through wealth, one TE wrote that "with laws being passed now so that businesses can sue individual people, massive logging companies can sue individual protesters for millions just to shut them up". Others wrote critically about the unequal distribution of power in Australia as "some groups of society are not treated equally, as evidenced by policies such as the Northern Territory intervention ${ }^{10}$ ". Another added that "Australian people do not have decision making power in proportion to how much they are affected by the decisions ... the wealthy have disproportionate power". Highlighting the superficiality of the choices available within the system, one wrote "that in reality we are dictated by the mainstream - white, middle-class and male - and the assumptions that everyone can access the things that make us powerful, and must necessarily want to, underpins our education and political systems". Another Academic added, ironically, that "even capitalism in this country is controlled by a minority".

PSTs, TEs and Ts who felt that Australia is very democratic, on the other hand, adopted a very uncritical acceptance of their previous thin definition of democracy, explaining their decision on the basis of thin conceptions, such as equality of rights, freedom of speech, and voting rights. Typical comments often made a comparison to other countries, including: "we are free to vote and speak out on issues that concern us without fear," "Australia is a fair country," "we have choice, rights and options in nearly every aspect of the community," "the government listens to what the majority of people want." and "processes are equal, just and fair for all citizens". One PST reflected the oftreferenced literature related to distrust of politicians, stating that despite having an opportunity to participate in elections: for example, "the final vote comes down to elected politicians who can have agendas of their own". One teacher wrote uncritically that Australia "instills and promotes the democratic principles of freedoms and rights, including separation of state and church; a free and fair electoral system; care for all citizens, support for refugees and those less well off, a universal education and medical system and economic and political stability". A number of Academics and

\footnotetext{
${ }^{10}$ The Northern Territory National Emergency Response (also referred to as "the intervention") was a package of changes to welfare provision, law enforcement, land tenure and other measures, introduced by the Australian federal government under John Howard in 2007, nominally to address claims of rampant child sexual abuse and neglect in Northern Territory Aboriginal communities. Operation Outreach, the intervention's main logistical operation conducted by a force of 600 soldiers and detachments from the ADF (including NORFORCE) concluded on 21 October 2008. The package was the Federal government's response to the Territory government's publication of Little Children are Sacred, but implemented only two out of ninety-seven of the report's recommendations. The response has been criticised, but also received bipartisan parliamentary support. The current Prime Minister Julia Gillard has and continues to support the response, though her predecessor Kevin Rudd did make some adjustments to its implementation.
} 
Teachers privileged an individualistic thin democracy, stating that "while power is given to the people, it is our own responsibility to make something of ourselves".

Other PSTs who thought Australia was very democratic still made reference to the hegemonic nature of class society, and that "there are many disenfranchised people. While they are compelled to vote by law, they do not genuinely have an equal say in how the country is run, they do not have equal opportunities for advancement, and they are seen by the majority (white, middle class) as in some way inferior". These respondents were also able to highlight the lack of a thicker democracy, suggesting that "I don't think we have a very active democracy but only when citizens take a stand against government action... it is not very democratic in its 'norms' and values". Academics also highlighted this contradiction of "a sense of inequality within the police system that favors the rich people in the country".

A number of PSTs also volunteered that they felt there is a strong link between education and democracy. They suggested that "some minority groups such as Indigenous people can sometimes not have their opinions heard due to a lack of education many people may also lack the knowledge of the working of this system failing to be beneficial for them ... it provides a great way of life for those that are educated". Again, this reflects an understanding that power can come with, and from, education. There was no such understanding evident among the serving teachers.

Academics, in a similar manner, highlighted the reality of the lack of choice between converging parties that, while the rights and freedoms associated with electoral politics "are on the right path to democracy, we still have not advanced ourselves as a nation to be completely democratic, although we do share the principals. We have elected governments so all citizens have the opportunity to have a say to a certain extent". Some were prepared to add major caveats that "if you are Muslim, there is a high level of mistrust by some members of society and government agencies. There are many groups of Australian society that are invisible or discriminated against through policy and the attitudes of others-[specifically] Aboriginal and Torres Strait Islanders". Rhetorically, one respondent asked "where are they in the commonly expounded history of Australia?"

It was not surprising that TEs, given their position of education and relative privilege were critical of the thinness of democracy and the dependence of "career politicians, with no alternative occupation to fall back on, need[ing] to get re-elected as their primary concern". The individual and, therefore, thin or non-participatory nature of democracy was referred to by many academics where "the seat of government is increasingly remote from ordinary Australians (who) are restricted from accessing the ears that are attached to those making decisions, (where) individual input into the genuine decision making process is minimal". These TEs mentioned that "people do not have decision making power in proportion to how much they are affected by the decisions and do not always have the right to voice opinions in places that matter". 


\subsection{Teaching about and for Democracy}

"We can learn that students have the power and intellect to mould their own education, because it is in fact their doing and their life of life-long learning ... democracy is in the way we allow students to un-tap their own inner light and power, and we cannot do that if we are stapled to a standard that is not prioritizing empowerment and critique and change." (PST)

"That is the best gift I can give the students I teach. Dissent is the most important activity in a classroom." (TE)

While responses to many of the questions in the survey differed dramatically among the groups of respondents, there was a previously unseen congruence between them to the question "Do you feel that teachers should inculcate a sense of democracy in students?" Ignoring the outliers among the TEs, we note that a very similar percentage of PSTs, Teachers and TEs (24\% and $28 \%)$ are unsure whether they should inculcate a sense of democracy in their students. However, 76\% of PSTs, $77 \%$ of Teachers, and $72 \%$ of TEs believed that they should, or most definitely must, inculcate democracy among their students.

Those who were unsure whether teachers should strive to inculcate a sense of democracy among their students were concerned about issues of potential conflicts of interest and bias when dealing with controversial topics. Whether one actually does this, however, a teacher said depends "on whether bias or ignorance influences their presentations". A PST stated that that "I think it happens already. Though I'm not sure if teachers are capable - parents should play the biggest part" while an TE added that it is important so long as it is done "without leaning to any side of politics" another TE added that "how do you do this without pushing you own views, or the views of one particular administration". A teacher found that doing so "confronts conflicting demands of the system" Another teacher rejected the importance of democracy instead suggesting that "it is more important that we nurture in students respect for others".

Some $(45 \%)$ of these respondents returned to the importance and primacy of voting and the electoral system highlighting that "students should be aware of the right to vote so use class discussions and decision making. Voting and agreeing on the best strategy ... I adopt a democratic approach [because] it's important to support students in developing an understanding of how the country is run and how decisions are made". Re-enforcing this hegemony of obedience some teachers thought democracy in schools was important because they "often take part in such practice of giving the students an understanding of democracy in terms of 'fair play' and values of individual's opinions".

The teachers' comments again reflect a thin understanding of democracy as being focused on the individual discussing the primacy of values and not actual participative action because it is "important to provide a direction and answer to the students and where their values lies on matter that effect them ... values are very important". "Democracy is a very important concept, and if we nurture those values in our students we can continue a legacy of freedom and the fight for equality". "Teachers are capable of manufacturing or nurturing any value in students is definitely important as students need to understand what happens regarding a democracy". Others referred back to their definition of democracy relating this to freedom of speech (but not necessarily to action) so that "it is very important for 
students to understand that their opinions count". A large number of the TEs also referred to values commenting that "teachers can nurture democratic values of students by allowing them to express their views of topics and problems".

PSTs who understood democracy more thickly commented that "educating students to be concerned, involved and contributing citizens of our country" was very important because "allowing students to critique and question and write letters to politicians ... we cannot do that if we are stapled to a standard that is not prioritizing empowerment and critique and change". One PST added that what is actually important is for teachers to learn that "students have the power and intellect to mould their own lives". Some TEs wanted to encourage more participatory understandings of democracy and suggested that teachers should encourage students to not only relate to each other, but also encourage collaboration and mutual support rather than competition among students. Moving beyond thin conceptions of democracy many (75\%) of the TEs made comments similar to the following describing their role as "one of fostering a belief in a better society for all through moral reasoning and critical thinking... despite being dictated to by less democratic forces".

\subsection{What are You Doing to Promote Democracy in the Classroom?}

"Inviting them to dissent. Encouraging dissent. Rewarding dissent" (TE)

When asked to think about what PSTs, teachers and TEs would do or were doing to promote democracy in their classrooms the responses ranged from "nothing directly" to extensively written narratives. More than $90 \%$ of respondents from each group wrote that they were doing something - but the nature of their classroom actions once again was often describing actions that reflect very thin understandings of democracy. Many PSTs focused not surprisingly on actions that might be considered part of a student-centered pedagogical approach to learning which in themselves promote an individualistic interpretation of participation and action. For example one PST wrote that "when I start teaching I would give as much choice as possible (without creating an inefficient and chaotic classroom), I would let them explore learning areas they are interested in and present them in ways that have real meaning to our society and world. What they learn at school should all be tools that they would use to do something about issues that are most important to them". And, the reason that this idea is recommended is not related to democracy at all, but because it would "hopefully make the work more meaningful".

Other PSTs wrote many ideas that included the notion of "giving choice" and "allowing students to have a say in tasks in the class" so that the students might "have input into what themes the class can look at to study" and that students would be learning according to "their interests and choices ... giving students information that they can use if they wish or not" as if such a laissez-faire approach to education was actually a reflection of democracy. Such misguided altruism is indicative of the superficiality present in thin democratic discourses. There was a belief that students "can find out alternative opinions if they wish to" and by giving students a choice they will be "encouraged to explore".

Here the PSTs fall back to their previous understandings of democracy as related to issues like freedom of expression and choice, lacking the understanding that for many of the children (and their 
families) in our schools, choice and freedom of expression is a highly contested and questionable attribute of their daily lives.

Many others also wrote that they would include teaching and learning activities that allowed students to vote on what they do in the classroom activities, again reflecting the thin democracy attributed in their definitions to the previous question. Voting, the sine qua non of liberal democracy will be replicated in these classrooms where the teachers will be teaching about democracy but not for democracy.

Many PSTs and current teachers (65\%) wrote about their students being involved in a variety of electorally based activities such as school or student councils, which they suggest allows students to have a "real say in matters that concern them and the school". Teachers explained that students "get to choose and to vote on issues" as their contribution to democratic education. Doing activities such as "electing their classmates as leaders of their class ... class discussions, circle time, interviews with students, parent teacher interviews, conflict mediation" were all common examples of opportunities for democratic practice, but all these refer to non-activist individualistic democracy that often serves to give an illusion of participation reflecting the illusory democracy of the electoral system. A number of teachers also spoke about the need to teach students the values that they associated with democratic practice such as "empathy, honesty, responsibility, respect, tolerance, striving for excellence, treating all students as equals, accepting and respecting". TEs wrote about the importance of values and vales education in the promotion of democracy in their classrooms in order to "show fairness and equality amongst the students ... to exhibit and promote democratic values ... modeling inclusion, value for rights and responsibility ... instilling the notion that we should all be treated equally ... being fair and inclusive and a good listener ... displaying democracy in the classroom, showing fairness and equality amongst the students". One commented that they promote democracy by being "true to myself and my morals and values collected over time". These again reflect the superficial references to the parenthood type statements about democracy.

There was however only a small number of PSTs, teachers and TEs (fewer than 5\% of each group) who spoke of empowering participation for students in activities such as not "just deciding on their own class rules", which was mentioned by many PSTs (who would probably have heard their TEs talking about this in their classroom management lectures) and teachers, but being "active in changing and managing their classroom environment". These few understood that what is required for democracy is "active participation in decision making ... that has a direct impact on them" where there would be "opportunities for student leadership in the school". Not only was it important they suggest for "students to have a say in classroom rules" but the reason for doing so is to "give students a say using democratic processes for real life purposes".

As discussed earlier the Discovering Democracy Project has been available for many years and despite its many shortcomings only two teachers referred directly to any program of a formal nature about education related to democracy. They wrote about how we teach democracy and civics and citizenship through their student leadership program and significantly, that they "also include electives on these topics from grades 3-6 in a shared and applied rotation program with units of work on democracy, human rights, civics and citizenship and elections". A large number (85\%) of TEs spoke about teaching how government works or about how policies and social history impact on their teaching and their students in their courses. Many TEs (75\%), similar to teachers, mentioned that they 
use opportunities for discussion about important topics and in "engaging in dialogue, discussing political issues, using student centered learning and choice in assessment tasks". They mention that democracy is included in their lectures, readings and assignments with some choice in what issues students explore in their assignment work. Again teaching about democracy is conflated with teaching for democracy and therefore remaining within a thin democratic discourse.

But often the discussion about active participation of students came with a caveat emptor that was most telling from one teacher who suggested that it was important to "allow children to have a say ... within parameters" and the need for them to be taught to "play within the rules" was all that needed to be done to achieve a democratic education. This kind of attitude reflects the illusory nature of superficial and thin democratic forms of classroom action that prepare young people to be passive recipients and not informed and active participants in society.

A small number $(5 \%)$ of TEs mentioned that they promote democracy by exploring the hegemony of power and control. They did this by helping students "to deconstruct the often incomprehensible books and papers they have to read" to reveal the ideologies hidden within the texts through "seeing what issues are being talked about and what their opinions were". These TEs wanted their students "to read up on issues that they thought were important" giving them the tools to be able to critically question every decision their government makes. Reflecting on the pervasiveness and power of the media in Australia their rationale was that they "don't want them to become sheep" so they encourage students in not only "negotiating power" but also through the raising of awareness of power differentials within systems and societies. By "asking students to know their own biases so that they are not blinded by their own experiences and engage students in examination of the assumptions that underpin the dominant thoughts in the field" these TEs were working within a thick democracy because these TEs stated that their students will be "enriched by these perspectives". Two TEs actually mentioned practices and actions that exemplify a thicker understanding of democracy which they use to promote democracy through "negotiation of the curriculum, assessment processes tasks; results and classroom practices with their students. They believed that through this they exhort, exemplify and provide experiential democratic learning".

\section{Discussion: A Broadly Neo-Liberal Agenda-Rhetoric of Active Participation: Learning About but not Doing Democracy}

How are we to understand and contextualise the contrasting and contradictory views presented here? Print [35] argues that the challenge to democracy is not from an external or internal enemy but from its own citizens "who have grown distrustful of politicians, sceptical about democratic institutions and disillusioned about how the democratic process functions" (p. 325). However, he points to the paradox of over 20 years of CCE that "as the demand for democratic citizenship grows, youth participation in formal democracy is declining" (p. 326). He reiterates the importance of "learning about participation ... developing of political engagement ... to learn about democracy, government and citizenship ... to acquire civic knowledge, and skills and values" (p. 336). He concludes that this may "enhance political knowledge and probably political engagement" (p. 336) ... [and] "can influence engagement and participation" (p. 337) in the future. Criticising "participatory pedagogy" (p. 338) as weak in schools, Print explains that "engaged or conversational pedagogy" 
epitomized by "class voting, group inquiry, simulations, fieldwork and co-operative learning" has a strong correlation with future civic engagement. This pedagogy only reinforces the illusion of democracy.

What emerges from the teachers surveyed is that their students are required to learn about democracy but to not — at least in a serious way — do democracy. Missing from their comments was a thorough understanding of what is a good citizen. The civics versus citizenship debate can be seen in terms of the struggle between thin and thick democracy. Giroux [36] suggests that because there has been a shift from responsibility for creating democracy of citizens to producing a democracy of consumers:

public education becomes a venue for making a profit, delivering a product, or constructing consuming subjects, education reneges on its responsibilities for creating a democracy of citizens by shifting its focus to producing a democracy of consumers. (p. 173)

Producing better curriculum materials will not in itself deliver the results expected or intended. Prior concludes that the existence of stand-alone unlinked or de-contextualised one-off programmes do not provide the lasting affects planned for, while the schools were accused by students of 'talking the talk but not walking the walk' because teachers were not able to model good citizenship in their practices. Seddon (p.172) concludes that:

contemporary education policy, practice and politics has become primarily framed within a dominant economic discourse which marginalises and obscures the political purposes of education necessary to the formation and sustainability of a democratic citizenry. The challenge is to re-acknowledge the crucial contribution of political education outcomes in sustaining democracy and to work for a pattern of citizen learning that accommodates necessary learning for work and life-with-risk, and also learning for citizen action that can imagine the democratic ideal, support ethical judgement and protect democratic decisionmaking [30].

\section{Conclusions}

This analysis raises concerns that much of the contemporary CCE may actually "privilege ... individual choice at the expense of public and democratic purposes for education ... [and] pose a significant threat to Australian democracy" [29]. How then can CCE be "remade to serve the purposes of a just and democratic society" [30]? Countering this requires what Seddon (p.171) calls a deliberatively thick democracy which "assumes ethical and informed citizens who participate as equals in the public sphere" [30].

Thick democracy goes beyond the championing of electoral and legislative processes, rule of law and basic civil rights [37]. It encourages and facilitates the legitimacy of collective citizen and civil action as external to government and business. Thick democracy envisages a 'social citizen'—an individual always in relationship with others - capable of reflexive agency [38]. Paradoxically, many of the democracy exporting countries are experiencing crises of democracy at home ${ }^{11}$.

\footnotetext{
${ }^{11}$ The massive youth led unrest of 2011 in England and Israel are examples of this phenomena.
} 
In contradistinction, the active citizen of neo-liberalism is conceived as an entrepreneur and a 'can do achiever' to benefit the individual. While schools are expected to prepare students to live in diverse democratic societies [17] the teachers in this research at least indicate that their school practices have remained largely undemocratic [39].

Thick democracy must be about "voice, agency, inclusiveness and collective problem solving" that is "rooted in the capacity to see oneself reflected in the cultures of society" [37], and not just in the freedom to pursue one's own individual self-interest. Howard and Patten [37] explain that, despite the common rhetoric of active citizenship, there are two perceptible trends within the new civics: the thin neo-liberal and the thick(er) radical democratic trends. They suggest that the latter is motivated by egalitarian commitments and "the desire to extend democracy while enhancing the political agency of once marginalised citizens" (p. 459). Being active in this sense means being "socially engaged and committed to collective problems solving at all levels of the political community" [37]. Democracy, then, is more than elections, and includes all power-structured social relationships. In essence, they explain that this requires the ability to "navigate and influence the power-structured social relations that characterize the politics of civil society" [37] (p. 460). It would, therefore, be advantageous that educators acknowledge that what is necessary is an equalisation of agency for students, otherwise this is not possible.

Thick democracy actively challenges the view that "unregulated markets are by definition realms of freedom that produce equality of opportunity" [37] with "extensive social and cultural citizenship rights" (p. 461) associated with a politicized empowerment in the social processes that shape society where all are visible and heard despite their social status. Thick democracy must be about "voice, agency, inclusiveness and collective problem solving" that is "rooted in the capacity to see oneself reflected in the cultures of society"[37] (pp. 462-3), and not in the freedom to pursue one's own individual self-interest. Therefore thick democratic teaching will be concerned with a recognitive, not just redistributive, social justice [40]. A thick democratic teaching is incorporated in Westheimer and Kahne's vision that goes beyond the personally responsible citizen of the so-called 'critical democracy ${ }^{12}$, urged by Dejaeghere and Tudball [19] to incorporate both the participatory and justice orientated citizen. Nevertheless, Westheimer and Kahne (pp. 242-243) warn:

While pursuit of both goals may well support development of a more democratic society, it is not clear whether making advances along one dimension will necessarily further progress on the other. Do programs that support civic participation necessarily promote students' capacities for critical analysis and social change? Conversely, does focusing on social justice provide the foundation for effective and committed civic actors? Or might such programs support the development of armchair activists who have articulate conversations over coffee, without ever acting [41]?

Thick democracy will not be easily achieved, in society, either generally or in schools, in particular. As the agents of society in which they exist, teachers (rightly) can claim they are, therefore, restricted in what they alone can achieve as the national agendas and budgets are nationally and state controlled.

\footnotetext{
${ }^{12}$ This is a distortion of Westheimer and Kahne's thesis which makes it clear that without real action and involvement there can be no thick democracy.
} 
The test for teacher educators, teachers and education students is to ask questions of, rather than to accept, neo-liberal received wisdom. Armstrong (p. 10) suggests that the definition of teaching as the uncritical transmission of knowledge begs the question of "what and how knowledge is constituted as a social and political stance towards the truth" [42].

Armstrong argues that as participation and dissent are central to democratic life, then these too should be central to systems that are fundamental to the contestation between a thin and thick democracy. For teachers:

These possibilities are revealed through dialogue with our students and in dialogues with the communities of policy and practice with whom we work. We cannot simply be concerned with the accumulation and transmission of knowledge and competencies; it is our duty to interrogate what is meant by knowledge and how it is formed and to understand the limits of competency. As educators we are engaged in a process of human inquiry that makes us human [42] (p. 10).

But can this be done without "education in and for democracy" [43] (p. 116)? School students cannot acquire the knowledge, attitudes and skills to successfully become agentic citizens without the simultaneous democratization of pedagogy, schools and school systems. The role-playing of democracy and pretend parliaments-recommended in CCE and reflected by the majority of respondents - means too often that students are involved in decision making on "an abstract and often detached level" [43]. Programs associated with a thin democracy are unable to take the "social organisation of specific schools and the everyday life of individual students into consideration" (p. 118). The responses detailed here indicate that it requires a change in educational practice at all levels to "inspire political empowerment" beyond the implementation of off the shelf products or programmes.

Civics related knowledge is necessary but not sufficient for "becoming a competent democratic citizen" [21]. However, thick democracy has the potential to become the site of struggle for social justice and equity, and not necessarily assimilationism [44].

Teachers have a choice between a thicker democracy that is reflective, critical, participatory, tolerant and non-hierarchical and a thinner, authoritarian democracy, based on uncritical knowledge, standards and competencies as the measure of the 'good citizen'. A thick democracy focuses on "how citizens understand themselves as members of a public with an obligation to promote the public good" [37] and the competencies required of civic citizenship that encompass informed and active citizens participating in political debate and action on equal terms [45]. Education needs to assume a "deep democratic engagement" [46]. The top-down imposition of policies designed by "teams of experts' is incompatible with thick democracy, and must be rejected, if we aspire to the true ideals of democracy, in favour of the active involvement of the least powerful [45].

There have been detailed studies of students' attitudes to democratic values and participation in society that conclude that while Australian students have a well-developed set of democratic values [47], they adopt a passive rather than an active style of engaging in conventional citizenship activities. Except for this study, there has not been any commensurate study on teachers, and, significantly, on pre-service teachers and their educators. In this light, Seddon [30] asks: 
How can education be remade to serve the purposes of a just and democratic society? How can education, in the context of a social order torn between neo-liberal free markets and neo-conservative family values and 'them'-'us' differentiations, develop an ethical citizenry and capable and creative contributors to the common good who will enable and protect civic society in a sustainable way? (p. 171)

No claim is being made that the views expressed by these participants are anything more than that and should not be seen necessarily as generalizable to the broader population. This current research indicates that the empirical and qualitative data analyzed suggests that practicing educators have a thin conception of democracy and if they indeed are typical of our current teachers then this raises many concerns for the health of democracy in Australia and also begs the question about the stickability of teacher education programs and the acknowledged pressures and influences of the old hands on new teachers to adopt accepted practices.

Further research will enable the development of a framework for conceptualizing democracy in education, highlighting, in particular, what educators can do to become more critically aware and engaged in democracy within their teaching.

Providing such comparative empirical and qualitative studies from the old, new and emerging democracies will provide further insight for the broader educational community and will serve to expand knowledge in education. Instead of education reproducing the current thin democracy that leads to disengaged citizens [19], examples of excellent teacher practice would enable the development of an educational framework of teaching for thick democracy in leading to a more participatory, empowered and engaged citizenry and a more inclusive participation in, and therefore safeguarding of, democratic society.

A more holistic and dynamic approach - pedagogical, experiential, political, social, economic and cultural - is a necessary step to attaining a more decent society, and to produce citizens who are engaged, critical, and productive agents of positive change.

\section{References}

1. Westheimer, J.; Kahne, J. What kind of citizen?: The politics of educating for democracy. Am. Educ. Res. J. 2004, 41, 237-269.

2. Carr, P.R. Experiencing democracy through neo-liberalism: The role of social justice in education. J. Crit. Educ. Policy Stud. 2007, 5, http://www.jceps.com/?pageID=article\&articleID=104.

3. Carr, P.R. Educators and education for democracy: Moving beyond "thin" democracy. Int. J. Educ. Democr. 2008, 1, 147-164.

4. Carr, P.R. Does Your Vote Count? Critical Pedagogy and Democracy; Peter Lang Publishing: New York, NY, USA, 2010; p. 333.

5. Lund, D.E.; Carr, P.R. Doing Democracy: Striving for Political Literacy and Social Justice; Peter Lang Pub Inc: New York, NY, USA, 2008.

6. Banks, J.A. Citizenship education and diversity: Implications for teacher education. J. Teach. Educ. 2001, 52, 5-16.

7. Porfilio, B.J.; Carr, P.R. Youth Culture, Education and Resistance: Subverting the Commercial Ordering of Life; Sense Publishers: Rotterdam, The Netherlands, 2010. 
8. Darder, A.; Miron, L.F. Critical pedagogy in a time of uncertainty: A call to action. Cult. Stud. Crit. Methodol. 2006, 6, 5-20.

9. Denzin, N.K. Critical pedagogy and democratic life or a radical democratic pedagogy. Cultural studies, critical methodologies 2009, 9, 379-397.

10. McLaren, P.; Kincheloe, J. Critical Pedagogy: Where Are We Now? Peter Lang: New York, NY, USA, 2007.

11. Carr, P.R. Re-thinking normative democracy and the political economy of education. J. Crit. Educ. Policy Stud. 2010, 8, http://www.jceps.com/?pageID=article\&articleID=175.

12. Carr, P.R.; Zyngier, D. Can Education Make a Difference? Experimenting with, and Experiencing, Democracy in Education; Information Age Publishing: Charlotte, NC, USA, 2012.

13. Westheimer, J. No Child Left Thinking: Democracy at-Risk in American Schools; University of Ottawa: Ottowa, Canada, 2008; volume 17.

14. Gandin, L.A.; Apple, M.W. Thin versus thick democracy in education: Porto alegre and the creation of alternatives to neo-liberalism. Int. Stud. Sociol. Educ. 2002, 12, 99-116.

15. Barber, B.R. Strong Democracy: Participatory Politics for a New Age; University of California Press: Berkeley, CA, USA, 1984; Chapter xvi, p. 320.

16. Barber, B.R. Strong Democracy: Participatory Politics for a New Age, 20th-anniversary ed.; University of California Press: Berkeley, CA, USA and London, UK, 2004; Chapter xxxvi, p. 320.

17. Furman, G.C.; Shields, C.M. How Can Educational Leaders Promote and Support Social Justice and Democratic Community in Schools. In A New Agenda for Educational Leadership; Firestone, W.A., Riehl, C., Eds.; Teachers College Press: New York, NY, USA, 2005; pp. 119-137.

18. Davies, I.; Issitt, J. Reflections on citizenship education in Australia, Canada and England. Comp. Educ. 2005, 41, 389-410.

19. Dejaeghere, J.G.; Tudball, L. Looking back, looking forward: Critical citizenship as a way ahead for civics and citizenship in Australia. Citizsh. Teach. Learn. 2007, 3, 40-57.

20. Giroux, H.A. Higher education under siege: Implications for public intellectuals. Thought Action NEA Higher Educ. J. 2006, Fall, 63-78.

21. Schwille, J.; Amadeo, J.-A. The Paradoxical Situation of Civic Education in Schools: Ubiquitous and Yet Exclusive. In International Perspectives on Education and Society; Emerald Group Publishing Limited: West Yorkshire, UK, 2002; volume 5, pp. 105-136.

22. Kahne, J.; Westheimer, J. Teaching democracy: What schools need to do. Phi Delta Kappan 2003, 85, 34-68.

23. Garratt, D.; Piper, H. Citizenship education in England and Wales: Theoretical critique and practical considerations. Teach. Teach. 2008, 14, 481-496.

24. Criddle, E.; Vidovich, L.; O’Neill, M. Discovering democracy: An analysis of curriculum policy for citizenship education. Int. J. Res. Method Educ. 2004, 27, 27-41.

25. Allard, A.; Johnson, E. Interrogating the Discourse of 'Social Literacies' In an Era of Uncertainty. In Proceedings of the Australian Association of Research in Education Annual Conference, University of Queensland, Brisbane, Queensland, Australia, 1-5 December 2002. 
26. Forsyth, A.; Tudball, L. Listening to the Voices of Teachers: How Should We Define and Implement Civics and Citizenship Education in the Future? In Proceedings of the Australian Association of Research in Education Annual Conference, University of Queensland, Brisbane, Queensland, Austrilia, 1-5 December 2002.

27. Knight, T. Longitudional Development of Educational Theory: Democracy and the classroom. In Proceedings of the Annual Conference Australian Association Research in Education, The University of Sydney, New South Wales, Austrilia, 4-7 December 2000.

28. Tudball, L. Changing Constructions of 'Social Education' in Victoria: New Challenges for Teachers. In Proceedings of the Australian Association of Research in Education Annual Conference, University of Melbourne, Vitoria, Australia, 27 November - 1 December, 2005.

29. Reid, A.; Thomson, P. Towards a Public Curriculum; Australian Curriculum Studies Association: Brisbane, Australia, 2003.

30. Seddon, T. Remaking civic formation: Towards a learning citizen? Lond. Rev. Educ. 2004, 2, 171-186.

31. Carr, P. Educating for democracy: With or without social justice. Teach. Educ. Q. 2008, Fall, 117-136.

32. Bourdieu, P.; Passeron, J. Reproduction in Education, Society and Culture, 2nd ed.; Routledge: London, UK, 1990.

33. Bernstein, B. Pedagogy, Symbolic Control, and Identity: Theory, Research, Critique; Taylor \& Francis: London, UK and Washington, DC, USA, 1996; Chapter xiv, p. 216.

34. Gramsci, A. Selections from the Prison Notebooks of Antonio Gramsci; Lawrence \& Wishart: London, UK, 1971; Chapter xcvi, p. 483.

35. Print, M. Citizenship education and youth participation in democracy. Br. J. Educ. Stud. 2007, 55, 325-345.

36. Giroux, H.A. Stealing Innocence: Youth, Corporate Power and the Politics of Culture; Palgrave: Basingstoke, UK, 2000; Chapter ix, p. 197.

37. Howard, C.; Patten, S. Valuing civics: Political commitment and the new citizenship education in Australia. Can. J. Educ. 2006, 29, 454-475.

38. Giddens, A. Beyond Left and Right: The Future of Radical Politics. Polity Press in association with Blackwell: Cambridge, UK, 1994; Chapter vii, p. 276.

39. Duignan, P.A. Socially responsible leadership: Schools for a more just and democratic society. Lead. Manag. 2005, 11, 1-13.

40. Gale, T.; Densmore, K. Engaging Teachers: Towards a Radical Democratic Agenda for Schooling; McGraw-Hill Open University: Maidenhead, UK and Philadelphia, PA, USA, 2003.

41. Westheimer, J.; Kahne, J. Educating the "good" citizen: Political choices and pedagogical goals. Polit. Sci. Polit. 2004, 37, 241-247.

42. Armstrong, D. Dreaming our future: Developing democratic professional practice? Aust. Educ. Res. 2006, 33, 1-11.

43. Dobozy, E. Effective learning of civic skills: Democratic schools succeed in nurturing the critical capacities of students. Educ. Stud. 2007, 33, 115-128.

44. Taylor, A. Education for democracy: Assimilation or emancipation for aboriginal Australians? Comp. Educ. Rev. 1996, 40, 426-438. 
45. Reid, A. Public education and democracy: A changing relationship in a globalizing world Reid A. J. Educ. Policy 2002, 17, 571-585.

46. Reid, A. Rethinking the Democratic Purposes of Public Schooling in a Globalizing World. In Globalizing Education: Policies, Pedagogies, \& Politics; Apple, M.W., Kenway, J., Singh, M., Eds.; Peter Lang: New York, NY, USA, 2005; Chapter vii, p. 311.

47. Walsh, L.; Black, R. In Their Own Hands: Can Young People Change Australia? ACER Press: Camberwel, UK, 2011; pp. 1-149.

(C) 2012 by the authors; licensee MDPI, Basel, Switzerland. This article is an open access article distributed under the terms and conditions of the Creative Commons Attribution license (http://creativecommons.org/licenses/by/3.0/). 